\title{
Kemampuan Afektif Calon Guru Sekolah Dasar Pada Pembelajaran Online Di Program Studi PGSD Universitas Muhammadiyah Pringsewu Lampung
}

\author{
Yesi Budiarti \\ Universitas Muhammadiyah Pringsewu Lampung \\ yesibudiarti@umpri.ac.id \\ Meita Dwi Solviana \\ Universitas Muhammadiyah Pringsewu Lampung \\ meytadwisolviana@umpri.ac.id
}

DOI:10.35719/educare.v2i2.68

\begin{abstract}
Abstrak
Learning is a conscious effort made by individuals to acquire various kinds of abilities (competencies), skills (skills), and attitudes (attitudes) through a series of learning processes that will ultimately result in behavioral changes in the individual. The learning process in schools tends to emphasize the achievement of changes in cognitive (intellectual) aspects which are carried out through various forms of approaches, strategies, and certain learning models. Learning systems that specifically develop affective abilities have received less attention, affective abilities are only used as a nurturing effect. This study aims to (1) find out whether online learning is able to bring out the affective abilities of prospective study program teachers (2) analyze the affective abilities of prospective teachers in online learning. The data used in this study is qualitative data. The technique used is a questionnaire. This questionnaire was given to respondents, namely students of PGSD teacher candidates at Muhammadiyah University of Pringsewu. The results of the study indicate that affective abilities can appear in online learning as evidenced by the results of the questionnaire that has been given to respondents. The indicators of affective ability in this study include attitudes, interests, self-concept, values, and morals, all of which are in the good range. This means that the results of students' affective abilities can be said to be valid or appear in online learning
\end{abstract}

Keywords: Affective Ability; e-learning; PGSD 


\begin{abstract}
Abstrak
Belajar merupakan upaya sadar yang dilakukan individu untuk memperoleh berbagai macam kemampuan (competencies), ketrampilan (skills), dan sikap (attitudes) melalui serangkaian proses belajar yang pada akhirnya akan menghasilkan perubahan tingkah laku pada individu tersebut. Proses pembelajaran di sekolah lebih cenderung menekankan pada pencapaian perubahan aspek kognitif (intelektual) yang dilaksanakan melalui berbagai bentuk pendekatan, strategi, dan model pembelajaran tertentu. Sistem pembelajaran yang secara khusus mengembangkan kemampuan afektif kurang mendapat perhatian, kemampuan afektif hanya dijadikan sebagai efek pengiring (nurturant effect). Penelitian ini bertujuan untuk (1) mengetahui apakah pembelajaran online mampu memunculkan kemampuan afektif calon guru prodi (2) menganalisis kemampuan afektif calon guru SD pada pembelajaran online. Data yang digunakan dalam penelitian ini yaitu kualitatif. Teknik yang digunakan ialah angket. Yang diberikan kepada 132 responden, Hasil penelitian menunjukkan bahwa kemampuan afektif dapat muncul pada pembelajaran online. Indikator kemampuan afektif dalam penelitian ini, meliputi sikap, minat, konsep diri, nilai, dan moral yang semuanya berada pada rentang baik. Hal ini berarti bahwa hasil kemampuan afektif calon guru sekolah dasar dapat dikatakan valid atau muncul pada pembelajaran online.
\end{abstract}

\title{
Kata Kunci: Kemampuan Afektif; e-learning; PGSD
}

\section{PENDAHULUAN}

Perkembangan teknologi informasi dan komunikasi sudah merambah dan mempengaruhi dunia pendidikan, yaitu pembelajaran dalam jaringan atau daring ${ }^{1}$. Hal ini terlihat dari pembelajaran yang dilakukan pengajar sudah memanfaatkan perkembangan teknologi informasi dengan tampilan power point dan sebagainya. Berdasar Hasil penelitian menyebutkan bahwa melalui power point, pembelajaran jarak jauh menjadi lebih menarik serta mudah untuk di pahami².

\footnotetext{
${ }^{1}$ Sofyana dan Rozak. Pembelajaran Daring Kombinasi Berbasis Whatshap pada Kelas Karyawan Prodi Teknik Informatika universitas PGRI Madiun. Jurnal Nasional Pendidikan Teknik Informatika, Vol.08 No.1 Maret. 2019.1-6.

${ }^{2}$ Yani, Yunita. Kreativitas Pembelajaran Jarak Jauh Dalam Era New Normal Di Min 1 Banyumas. Iain Purwokerto. 2021. [Http://Repository.Iainpurwokerto.Ac.Id/9615/] Diakses 10 November 2021.
} 
Saat ini mahasiswa dengan semua peralatan elektroniknya dapat memanfatkan berbagai macam jejaring sosial (facebook, twitter, dan lainlain) untuk mengakses segala informasi dari seluruh belahan dunia tanpa batas waktu maupun tempat. Adanya jejaring sosial ini juga membuat siswa/mahasiswa menjadi terbiasa atau akrab dengan dunia online. Inovasi bidang teknologi sejalan dengan inovasi pembelajaran melalui komputer dapat terakses ke internet ${ }^{3}$. Pembelajaran seperti ini disebut pembelajaran berbasis web (on-line learning) atau biasa dikenal dengan istilah $e$-learning. Sistem pembelajaran ini merupakan bentuk implementasi pembelajaran yang memanfaatkan teknologi dan tidak dibatasi oleh ruang dan waktu. Pemanfaatan teknologi tersebut selain sebagai upaya mengatasi permasalahan teknis pembelajaran, juga sebagai upaya menjawab masalah substansial pembelajaran yang dituntut dalam perubahan paradigma pembelajaran.

Belajar merupakan upaya sadar yang dilakukan individu untuk memperoleh berbagai macam kemampuan (competencies), ketrampilan (skills), dan sikap (attitudes) melalui serangkaian proses belajar yang pada akhirnya akan menghasilkan perubahan tingkah laku pada individu tersebut. Perubahan tingkah laku yang diperoleh melalui proses belajar secara keseluruhan meliputi aspek kognitif, afektif, dan psikomotorik. Namun dalam prakteknya, proses pembelajaran di sekolah lebih cenderung menekankan pada pencapaian perubahan aspek kognitif (intelektual) yang dilaksanakan melalui berbagai bentuk pendekatan, strategi, dan model pembelajaran tertentu. Sistem pembelajaran yang secara khusus mengembangkan kemampuan afektif kurang mendapat perhatian, kemampuan afektif hanya dijadikan sebagai efek pengiring (nurturant effect) atau menjadi hidden curriculum, yang disisipkan dalam kegiatan

\footnotetext{
${ }^{3}$ Mustakim, Dasa. On-line learning: Suatu Paradigma Baru dalam Pembelajaran Matematika. E-Journal vol. 4 No.2 Edisi Januari. STKIP Modern Ngawi. http://ejournal.stkipmodernngawi.ac.id/index.php/jpm/article/view/19. 2019 Diakses tanggal 10 November 2021
} 
pembelajaran yang utama yaitu pembelajaran kognitif atau pembelajaran psikomotor. Kemampuan afektif (affective responses) siswa terbagi menjadi lima tingkatan, yaitu penerimaan (receiving), penanggapan (responding), penilaian (valuing), pengelolaan atau pengaturan (organizing), dan pengkarakterisasian atau bermuatan nilai (characterizing).

Hasil angket terhadap analisis kemampuan afektif pada pembelajaran online mahasiswa prodi PGSD Universitas Muhammadiyah Pringsewu Lampung menunjukkan bahwa kemampuan afektif mahasiswa masih kurang pada pembelajaran online.

Berdasarkan hasil angket awal tersebut, masalah pada mahasiswa PGSD Universitas Muhammadiyah Pringsewu Lampung yang paling penting dan mungkin untuk dicarikan solusinya adalah rendahnya kemampuan afektif siswa. Akar masalah yang menyebabkan masih kurangnya kemampuan afektif siswa antara lain adalah karena strategi pembelajaran online yang digunakan kurang memberikan kesempatan pada siswa untuk berpartisipasi dalam proses pembelajaran. Pembelajaran yang dilaksanakan masih terpusat pada aspek kognitif dan psikomotorik sedangkan kemampuan afektif hanya sebagai efek pengiring (nurturant effect).

Sebuah proses pembelajaran daring menyebabkan kemampuan afektif siswa menjadi tidak terlihat, afektif siswa harus ditanamkan karena ranah afektif menentukan keberhasilan belajar seseorang, kemampuan afektif harus ditanamkan ketika pembelajaran daring, seperti tanggung jawa siswa ketika guru memberikan tugas yang harus diselesaikan tepat waktu ${ }^{4}$. Pembelajaran online mempunyai dampak negatif yang timbul bagi kemampuan afektif siswa yang menurun seperti kurangnya kemandirian dan

\footnotetext{
${ }^{4}$ Arina, dkk. Analisis kemampuan afektif peserta didik dalam pembelajaran daring pada mata pelajaran pendidikan agama islam di smp negeri 9 malang. Vicratina: Jurnal Pendidikan Islam Vol.6 Nomor 6 Tahun 2021 e-ISSN: 2087-0678X
} 
tanggungjawab ${ }^{5}$. Belajar secara online kemampuan afektif cenderung rendah dan kurang baik. Sikap siswa yang menunjukkan kurang baik baik adalah kedisiplinan siswa dalam belajar, tanggung jawab dan kemandirian siswa serta minat dan perhatian siswa saat proses pelaksanaan pembelajaran.

Berdasarkan latar belakang tersebut peneliti mengangkat judul penelitian yaitu Analisis Kemampuan Afektif pada Pembelajaran Online Prodi PGSD Universitas Muhammadiyah Pringsewu.

\section{METODE PENELITIAN}

Sesuai dengan bentuk pendekatan penelitian kualitatif dan sumber data yang akan digunakan, maka teknik pengumpulan data yang digunakan adalah dengan angket. Metode penelitian menggunakan deskriptif kualitatif. Pengumpulan data yang digunakan adalah observasi, wawancara serta kuesioner/angket. Kuesioner yang digunakan berbentuk google form (online) yang memiliki 5 indikator kemampuan afektif, antara lain : (1) sikap; (2) minat; (3) konsep diri; (4) nilai; dan (5) moral.. Subyek dan tempat dalam penelitian ini adalah mahasiswa PGSD semester 2 Universitas Muhammadiyah Pringsewu Lampung yang berjumlah 139 orang mahasiswa.

Angket yang digunakan dalam penelitian ini adalah tipe tertutup. Tipe angket ini merupakan tipe yang pilihan jawaban pernyataannya telah disediakan dalam angket, seperti pilihan jawaban "ya" atau "tidak". Angket tanggapan mengenai analisis kemampuan afektif terhadap pembelajaran online ini diberikan. Berikut, Tabel kisi-kisi angket tanggapan mengenai analisis kemampuan afektif terhadap pembelajaran online yang digunakan dalam penelitian dapat dilihat pada Tabel sebagai berikut:

\footnotetext{
${ }^{5}$ Luthfiyah, Fakkah Muhsinah .Kemampuan Afektif Siswa dalam Pembelajaran Jarak Jauh (PJJ) (Penelitian Mix Method di MI Cokroaminoto Banyuresmi Garut). [ http://digilib.uinsgd.ac.id/41208/] diakses tanggal 10 November 2021
} 
Tabel 1. Kisi-kisi Angket Tanggapan Analisis Kemampuan Afektif terhadap Pembelajaran Online

\begin{tabular}{|c|c|c|}
\hline No. & Indikator & Pertanyaan/Pernyataan \\
\hline 1. & Sikap & $\begin{array}{l}\text { 1. Saya senang melakukan perkuliahan dengan cara } \\
\text { online } \\
\text { 2. Saya senang mempelajari materi sebelum } \\
\text { perkuliahan di mulai } \\
\text { 3. Saya jarang bertanya ketika proses perkuliahan } \\
\text { berlangsung } \\
\text { 4. Saya mempunyai buku pendukung semua mata } \\
\text { kuliah } \\
\text { 5. Saya selalu mengerjakan tugas tepat waktu }\end{array}$ \\
\hline 2. & Minat & $\begin{array}{l}\text { 1. Saya memiliki materi lengkap setiap mata kuliah } \\
\text { 2. Saya selalu mencatat hal-hal yang penting setiap } \\
\text { mata kuliah } \\
\text { 3. Saya selalu menyiapkan pertanyaan sebelum } \\
\text { perkuliahan di mulai } \\
\text { 4. Saya selalu memahami materi setiap mata kuliah } \\
\text { 5. Saya berusaha hadir pada setiap jam perkuliahan } \\
\text { online }\end{array}$ \\
\hline 3. & $\begin{array}{l}\text { Konsep } \\
\text { Diri }\end{array}$ & $\begin{array}{l}\text { 1. Saya sulit mengikuti perkuliahan online } \\
\text { 2. Saya mudah memahami materi perkuliahan secara } \\
\text { online } \\
\text { 3. Saya merasa sulit mengerjakan tugas pada } \\
\text { perkuliahan online } \\
\text { 4. Saya mampu mengerjakan tugas perkuliahan online } \\
\text { 5. Saya memerlukan waktu lebih lama untuk } \\
\text { memahami materi pada perkuliahan online }\end{array}$ \\
\hline 4. & Nilai & $\begin{array}{l}\text { 1. Saya yakin bahwa prestasi saya lebih baik di } \\
\text { semester ini } \\
\text { 2. Saya yakin bahwa dosen sudah maksimal } \\
\text { menjalankan tugasnya } \\
\text { 3. Saya yakin bahwa setelah saya mengikuti proses } \\
\text { perkuliahan, kehidupan saya akan lebih baik ke } \\
\text { depannya } \\
\text { 4. Saya yakin bahwa setelah kuliah, ada peningkatan } \\
\text { kesejahteraan keluarga } \\
\text { 5. Saya yakin bahwa hasil belajar yang saya peroleh } \\
\text { adalah hasil usaha saya }\end{array}$ \\
\hline 5. & Moral & $\begin{array}{l}\text { 1. Saya selalu minta bantuan orang lain ketika } \\
\text { mengalami masalah perkuliahan } \\
\text { 2. Saya memberikan salam setiap bertemu dosen, }\end{array}$ \\
\hline
\end{tabular}




\begin{tabular}{|l|l|}
\hline & \multicolumn{2}{|c|}{ walaupun dalam perkuliahan online } \\
3. Saya yakin bahwa saya mampu menyelesaikan \\
kesulitan saya dalam mengikuti perkuliahan online \\
4. Saya suka membantu teman yang kesulitan \\
mengerjakan tugas kuliah online \\
5. Saya tidak mudah percaya dengan cerita orang lain
\end{tabular}

\section{HASIL DAN PEMBAHASAN TEMUAN}

\section{HASIL TEMUAN}

Adapun hasil pengamatan kemampuan afektif pada pembelajaran online Prodi PGSD Universitas Muhammadiyah setelah diukur dengan menggunakan lembar angket kemampuan afektif (affective responses).

\section{Hasil Angket Kemampuan Afektif}

Hasil angket kemampuan afektif mahasiswa PGSD Universitas Muhammadiyah pada tiap indikator dapat dilihat pada Grafik.

\section{Hasil Angket}

Perolehan hasil dari tanggapan responden mengenai analisis kemampuan afektif pada pembelajaran online ditinjau dari lima aspek yang telah diamati, yakni: (1) sikap; (2) minat; (3) konsep diri; (4) nilai; dan (5) moral, telah dianalisis dan dideskripsikan pada bab ini. Hasil persentase skor angket analisis kemampuan afektif pada pembelajaran online pada aspek sikap terdapat pada tabulasi berikut ini:

Tabel 2. Hasil Persentase Angket Analisis Kemampuan Afektif pada Pembelajaran Online Aspek Sikap

\begin{tabular}{|l|l|c|c|}
\hline No. & \multicolumn{1}{|c|}{ Pernyataan } & \multicolumn{2}{|c|}{ Persentase } \\
\cline { 3 - 4 } & \multicolumn{1}{|c|}{ Ya } & Tidak \\
\hline 1. & $\begin{array}{l}\text { Saya senang melakukan perkuliahan dengan } \\
\text { cara online }\end{array}$ & $69,1 \%$ & $30,9 \%$ \\
\hline 2. & $\begin{array}{l}\text { Saya senang mempelajari materi sebelum } \\
\text { perkuliahan di mulai }\end{array}$ & $76,3 \%$ & $23,7 \%$ \\
\hline 3. & $\begin{array}{l}\text { Saya jarang bertanya ketika proses } \\
\text { perkuliahan berlangsung }\end{array}$ & $53,2 \%$ & $46,8 \%$ \\
\hline 4. & $\begin{array}{l}\text { Saya mempunyai buku pendukung semua } \\
\text { mata kuliah }\end{array}$ & $87,7 \%$ & $12,2 \%$ \\
\hline 5. & Saya selalu mengerjakan tugas tepat waktu & $94,2 \%$ & $5,8 \%$ \\
\hline
\end{tabular}


\begin{tabular}{|l|l|l|}
\hline$\%$ Ya dan Tidak terhadap Keseluruhan Indikator & $12,17 \%$ & $7,83 \%$ \\
\hline
\end{tabular}

Merujuk pada tabulasi di atas, hasil perolehan dari tanggapan responden terhadap analisis kemampuan afektif pada pembelajaran online pada aspek sikap secara keseluruhan memiliki kriteria baik.

Tabel 3. Hasil Persentase Angket Analisis

Kemampuan Afektif pada Pembelajaran Online Aspek Minat

\begin{tabular}{|r|l|c|c|}
\hline \multirow{2}{*}{ No. } & \multicolumn{1}{|c|}{ Pernyataan } & \multicolumn{2}{|c|}{ Persentase } \\
\cline { 2 - 4 } & $\begin{array}{l}\text { Saya memiliki materi lengkap setiap mata } \\
\text { kuliah }\end{array}$ & $\begin{array}{c}51,8 \\
\%\end{array}$ & Tidak \\
\hline & $\begin{array}{l}\text { Saya selalu mencatat hal-hal yang penting } \\
\text { setiap mata kuliah }\end{array}$ & $\begin{array}{c}86,3 \\
\%\end{array}$ & $13,7 \%$ \\
\hline & $\begin{array}{l}\text { Saya selalu menyiapkan pertanyaan sebelum } \\
\text { perkuliahan di mulai }\end{array}$ & $\begin{array}{c}61,9 \\
\%\end{array}$ & $38,1 \%$ \\
\hline & $\begin{array}{l}\text { Saya selalu memahami materi setiap mata } \\
\text { kuliah }\end{array}$ & $77 \%$ & $23 \%$ \\
\hline 5 & $\begin{array}{l}\text { Saya berusaha hadir pada setiap jam } \\
\text { perkuliahan online }\end{array}$ & $100 \%$ & $0 \%$ \\
\hline & Ya dan Tidak terhadap Keseluruhan Indikator & 14,10 & $5,90 \%$ \\
\hline
\end{tabular}

Merujuk pada tabulasi di atas, hasil perolehan dari tanggapan responden terhadap analisis kemampuan afektif pada pembelajaran online pada aspek minat secara keseluruhan memiliki kriteria baik.

Tabel 4. Hasil Persentase Angket Analisis Kemampuan Afektif pada Pembelajaran Online Aspek Konsep Diri

\begin{tabular}{|c|l|c|c|}
\hline \multirow{2}{*}{ No. } & \multicolumn{1}{|c|}{ Pernyataan } & \multicolumn{2}{c|}{ Persentase } \\
\cline { 2 - 4 } 1. & Saya sulit mengikuti perkuliahan online & Ya & Tidak \\
\hline & $\begin{array}{l}\text { Saya mudah memahami materi perkuliahan } \\
\text { secara online }\end{array}$ & $51,9 \%$ & $28,1 \%$ \\
\hline 3. & $\begin{array}{l}\text { Saya merasa sulit mengerjakan tugas pada } \\
\text { perkuliahan online }\end{array}$ & $45,3 \%$ \\
\hline 4. & $\begin{array}{l}\text { Saya mampu mengerjakan tugas perkuliahan } \\
\text { online }\end{array}$ & $71,2 \%$ & $28,8 \%$ \\
\hline 5. & $\begin{array}{l}\text { Saya memerlukan waktu lebih lama untuk } \\
\text { memahami materi pada perkuliahan online }\end{array}$ & $55 \%$ & $5 \%$ \\
\hline
\end{tabular}




\begin{tabular}{|l|c|c|}
\hline$\%$ Ya dan Tidak terhadap Keseluruhan Indikator & $\begin{array}{c}10,91 \\
\%\end{array}$ & $9,09 \%$ \\
\hline
\end{tabular}

Merujuk pada tabulasi di atas, hasil perolehan dari tanggapan responden terhadap analisis kemampuan afektif pada pembelajaran online pada aspek konsep diri secara keseluruhan memiliki kriteria baik.

Tabel 5. Hasil Persentase Angket Analisis Kemampuan Afektif pada Pembelajaran Online Aspek Nilai

\begin{tabular}{|c|c|c|c|}
\hline \multirow[b]{2}{*}{ No. } & \multirow{2}{*}{ Pernyataan } & \multicolumn{2}{|c|}{ Persentase } \\
\hline & & Ya & Tidak \\
\hline 1 & $\begin{array}{l}\text { Saya yakin bahwa prestasi saya lebih baik di } \\
\text { semester ini }\end{array}$ & $82 \%$ & $28 \%$ \\
\hline 2 & $\begin{array}{l}\text { Saya yakin bahwa dosen sudah maksimal } \\
\text { menjalankan tugasnya }\end{array}$ & $\begin{array}{c}89,9 \\
\%\end{array}$ & $\begin{array}{c}10,1 \\
\%\end{array}$ \\
\hline 3 & $\begin{array}{l}\text { Saya yakin bahwa setelah saya mengikuti proses } \\
\text { perkuliahan, } \\
\text { kehidupan saya akan lebih baik ke depannya }\end{array}$ & $\begin{array}{c}95,7 \\
\%\end{array}$ & $4,3 \%$ \\
\hline 4 & $\begin{array}{l}\text { Saya yakin bahwa setelah kuliah, ada peningkatan } \\
\text { kesejahteraan keluarga }\end{array}$ & $95 \%$ & $5 \%$ \\
\hline 5 & $\begin{array}{l}\text { Saya yakin bahwa hasil belajar yang saya peroleh } \\
\text { adalah hasil usaha saya }\end{array}$ & $\begin{array}{c}99,3 \\
\%\end{array}$ & $0,7 \%$ \\
\hline \multicolumn{2}{|r|}{$\%$ Ya dan Tidak terhadap Keseluruhan Indikator } & $\begin{array}{c}18,47 \\
\%\end{array}$ & $\begin{array}{c}1,53 \\
\%\end{array}$ \\
\hline
\end{tabular}

Merujuk pada tabulasi di atas, hasil perolehan dari tanggapan responden terhadap analisis kemampuan afektif pada pembelajaran online pada aspek nilai secara keseluruhan memiliki kriteria baik.

Tabel 6. Hasil Persentase Angket Analisis Kemampuan Afektif pada Pembelajaran Online Aspek Moral

\begin{tabular}{|c|l|c|c|}
\hline \multirow{2}{*}{ No. } & \multicolumn{1}{|c|}{ Pernyataan } & \multicolumn{2}{|c|}{ Persentase } \\
\cline { 3 - 4 } 1. & $\begin{array}{l}\text { Saya selalu minta bantuan orang lain ketika } \\
\text { mengalami masalah perkuliahan }\end{array}$ & Ya & Tidak \\
\hline 2. & $\begin{array}{l}\text { Saya memberikan salam setiap bertemu dosen, } \\
\text { walaupun dalam perkuliahan online }\end{array}$ & $77 \%$ & $23 \%$ \\
\hline & $\begin{array}{l}\text { Saya yakin bahwa saya mampu menyelesaikan } \\
\text { kesulitan saya dalam mengikuti perkuliahan } \\
\text { online kehidupan saya akan lebih baik ke } \\
\text { depannya }\end{array}$ & $63 \%$ \\
\hline
\end{tabular}




\begin{tabular}{|c|l|c|c|}
\hline 4. & $\begin{array}{l}\text { Saya suka membantu teman yang kesulitan } \\
\text { mengerjakan tugas kuliah online }\end{array}$ & $92,1 \%$ & $7,9 \%$ \\
\hline & $\begin{array}{l}\text { Saya tidak mudah percaya dengan cerita orang } \\
\text { 5. lain }\end{array}$ & $89,2 \%$ & $10,8 \%$ \\
\hline \% Ya dan Tidak terhadap Keseluruhan Indikator & $\begin{array}{c}17,96 \\
\%\end{array}$ & $2,04 \%$ \\
\hline
\end{tabular}

Merujuk pada tabulasi di atas, hasil perolehan dari tanggapan responden terhadap analisis kemampuan afektif pada pembelajaran online pada aspek moral secara keseluruhan memiliki kriteria baik.

Data Analisis menggunakan teori Miles dan Huberman ${ }^{6}$ menggunakan mereduksi data, data display, dan pengambilan keputusan. Berdasarkan analisis yang dilakukan terhadap kemampuan afektif mahasiswa pada setiap pernyataan dapat diketahui bahwa capaian kemampuan afektif mahasiswa sudah sepenuhnya dapat mencapai presentase capaian target yang telah ditargetkan, antara lain : Pada aspek sikap \% Ya dari setiap indikator sebesar $12,17 \%$, aspek minat sebesar $14,10 \%$, aspek konsep diri sebesar $10,91 \%$, aspek nilai sebesar 18,47 \%, dan aspek moral sebesar 17,96 \%.

Dengan demikian, tindakan dalam analisis kemampuan afektif pada pembelajaran online sudah berhasil dan dapat mencapai target yang telah ditentukan. Ketercapaian target yang telah ditentukan pada variabel yang diukur dapat dilihat dengan membandingkan presentase yang diperoleh dari berbagai sumber data dengan presentase target yang telah ditentukan. Hal ini berarti bahwa data hasil penelitian tentang analisis kemampuan afektif siswa dapat dikatakan valid atau muncul pada pembelajaran online. Berdasarkan analisis seluruh hasil penelitian yang diperoleh melalui angket bahwa penerapan pembelajaran online dapat memunculkan kemampuan afektif siswa dengan perolehan persentase secara keseluruhan sebesar 73,61

\footnotetext{
${ }^{6}$ Miles, M.B, Huberman,A.M, dan Jhon Saldana. Qualitative Data Analysis, A Methods Sourcebook, Edition 3. (USA: Sage Publications. Terjemahan Tjetjep Rohindi Rohidi, UIPress, 2014).
} 
\% sehingga dapat dikatakan masuk kategori atau kriteria cenderung baik, disimpulkan dalam grafik berikut ini :

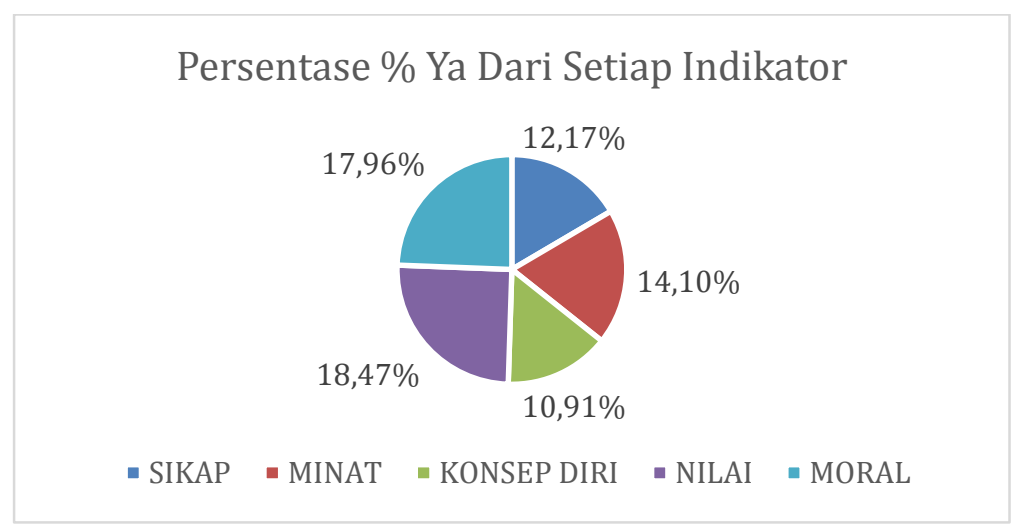

Gambar 1. Grafik Persentase \% Ya dari Setiap Indikator Analisis Kemampuan Afektif pada Pembelajaran
Online

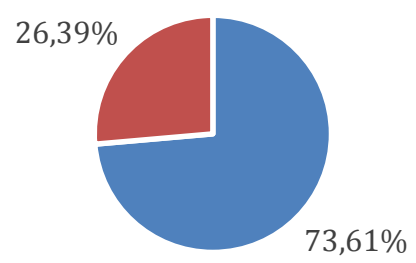

- Ya - Tidak

Gambar 2. Grafik Analisis Keseluruhan Kemampuan Afektif pada Pembelajaran Online

\section{PEMBAHASAN TEMUAN}

Pembelajaran online pada Prodi PGSD Universitas Muhammadiyah Pringsewu yang dilakukan, sudah mampu memunculkan kemampuan afektif mahasiswa. Berdasarkan perhitungan analisis data, diperoleh hasil bahwa secara verbal dapat dikategorikan kemampuan afektif mahasiswa pada pembelajaran online di kriteria baik. Aspek sikap mempunyai nilai rata-rata 76,1. Aspek minat mempunyai nilai rata-rata 75,4. Aspek konsep diri 
mempunyai rata-rata 74,68. Aspek nilai mempunyai rata-rata 92,38, serta aspek moral mempunyai nilai rata-rata 89,78.

Mahasiswa memiliki kesulitan dalam memahami konsep diri, hal ini dapat dilihat dari perolehan nilai yang paling rendah. Konsep diri merupakan kegiatan evaluasi diri terhadap keadaan fisik, psikis, sosial, dan pengharapan. menyatakan Konsep diri sangat berpengaruh terhadap motivasi dan prestasi belajar ${ }^{7}$. Mahasiswa yang mempunyai konsep diri yang baik akan membawa kepada perilaku-perilaku yang bersifat positif, serta dapat mengetahui kelemahan dan kekurangan yang ada pada dirinya ${ }^{8}$.

Sebaliknya, pada aspek nilai mahasiswa memiliki nilai paling tinggi, hal ini membuktikan adanya harapan yang tinggi dari mahasiswa untuk perbaikan status sosial ekonomi setelah menjalani pembelajaran secara daring. Kaitannya dengan pembelajaran. Dalam sebuah proses pembelajaran, nilai merupakan unsur penting dalam kemampuan afektif mahasiswa. Nilai seseorang dapat mengacu kepada hasil akhir dari pencapaian pembelajaran. Berdasarkan data angket, mahasiswa merasa mempunyai keyakinan untuk berprestasi lebih baik, yakin bahwa dosen sudah maksimal dalam menjalankan tugasnya, yakin bahwa kehidupan akan lebih baik, dan ada peningkatan kesejahteraan keluarga.

\footnotetext{
${ }^{7}$ Hariyadi dan Agus. Prestasi dan motivasi belajar dengan konsep diri. Prosiding Seminar Nasional PGSD Universitas Muria Kudus IKIP PGRI Bojonegoro.2019. [pgsd.umk.ac.id] Diakses tanggal 10 November 2021

${ }^{8}$ Saftari dan Fajriah. Penilaian ranah afektif dalam bentuk penilaian skala sikap untuk menilai hasil belajar. Edutainment : Jurnal Ilmu Pendidikan dan Kependidikan Vol.7 No. 1 Edisi Januari-Juni 201971 ISSN Online : 2656 - 5854 ISSN.1-11.
} 


\section{SIMPULAN}

Kemampuan afektif pada pembelajaran online di program studi PGSD universitas Muhammadiyah Pringsewu Lampung berada pada criteria baik. Berdasarkan beberapa aspek kemampuan afektif, yaitu; sikap, minat, konsep diri, nilai, dan moral. Terdapat satu aspek yang mempunyai nilai paling rendah, yaitu konsep diri. Sehingga perlu dilakukan penelitian lebih lanjut, bagaimana mahasiswa mempunyai konsep diri yang baik, agar mempunyai penyelesaian dalam mengikuti dan memahami perkuliahan, serta mampu mengerjakan tugas perkuliahan secara online.

\section{DAFTAR PUSTAKA}

Arina. dkk. Analisis Kemampuan Afektif Peserta Didik Dalam Pembelajaran Daring Pada Mata Pelajaran Pendidikan Agama Islam Di Smp Negeri 9 Malang. VICRATINA: Jurnal Pendidikan Islam Vol.6 No. 6 e-ISSN: 2087-0678X .Tahun 2021.

Hariyadidan Agus Darmuki. Prestasi Dan Motivasi Belajar Dengan Konsep Diri Ikip Pgri Bojonegoro. Prosiding Seminar Nasional. Program Studi Pendidikan Guru Sekolah Dasar Universitas Muria Kudus. [pgsd.umk.ac.id]. 2019. Diakses tanggal 10 November 2021.

L. Sofyana. Pembelajaran Daring Kombinasi Berbasis Whatshap pada Kelas Karyawan Prodi Teknik Informatika universitas PGRI Madiun. Jurnal Nasional Pendidikan Teknik Informatika, Volume 08 Nomor 1 Maret. 2019.

Luthfiyah, Fakkah Muhsinah. Kemampuan Afektif Siswa dalam Pembelajaran Jarak Jauh (PJJ) Digital Library UIN sunan Gunung Jati.[ http://digilib.uinsgd.ac.id/41208/] diakses tanggal 10 November 2021. 
M.Chodzirin. 2012. Formulasi Model Perkuliahan Daring Sebagai Upaya Menekan Disparitas Kualitas Perguruan Tinggi. Jurnal of Information Technology, Vol.1 No. 2. Semarang: Universitas Islam Negri Walisongo.

Maya Saftari1 dan Nurul Fajriah. Penilaian Ranah Afektif Dalam Bentuk Penilaian Skala Sikap Untuk Menilai Hasil Belajar. Edutainment : Jurnal Ilmu Pendidikan dan Kependidikan Vol.7 No.1 ISSN Online : 2656 - 5854 ISSN Cetak: 2303 - 372x STMIK Atma Luhur. Edisi Januari-Juni 2019.

Miles, M.B, Huberman,A.M, dan Saldana,J. Qualitative Data Analysis, A Methods Sourcebook, Edition 3. USA: Sage Publications. Terjemahan Tjetjep Rohindi Rohidi, UI-Press. 2014.

Mustakim, Dasa. 2019. On-line learning: Suatu Paradigma Baru dalam Pembelajaran Matematika. E-Journal vol. 4 No.2 Edisi Januari. STKIP Modern Ngawi.

Yani, Yunita. 2021. Kreativitas Pembelajaran Jarak Jauh Dalam Era New Normal Di Min 1 Banyumas. Iain Purwokerto. Http://Iainpurwokerto.Ac.Id/9615/ diakses tanggal 10 November 2021. 